\title{
NMR顕微鏡で生物や食品を見る
}

\section{石田信昭*!, 狩野広美*2}

*1 農林水産省食品総合研究所, ${ }^{* 2}$ 同省農業生物資源研究所

NMR 顕微鏡は, MRI (magnetic resonance imaging）装置で画像の分解能（pixel）を顕微鏡レベル（実 体顕微鏡および光学顕微鏡レベル, $100 \mu \mathrm{m} \times 100 \mu \mathrm{m}$ 程 度以下）に向上させた装置であり，基本的な測定原理は MRI と同じである. MRI は NMR (nuclear magnetic resonance；核磁気共鳴）によって生体中の特定の核の スピンの分布を画像化する．生体組織にはスピンモー メントをもつプロトンを含を水や油が多量に存在して いるので，MRI で容易に非破壊的に組織の形態的なイ メージが得られるが，それは本質的に形態的な情報とい うよりも組織の物理化学的, または生化学的な情報を画 像化したものといえる。すなわち，NMR は化合物分子 の構造のミクロな情報を与えるので化合物の同定などに 用いられるが，MRI は NMR 本来の基本的な性質を備 えたまま空間的な分解能を付加されたものとして捉觉る ことが可能である。しかし，イメージ構成技術上，また は生体組織の特性によって NMR 本来の性質が部分的 に損なわれるので，MRI に抢汸る NMR の限界を考虑 しつつ顕微鏡レベルに拈ける MRI と MRI 装置によ る分光法について述べる.

\section{基本的な測定原理}

光学顕微鏡ではレンズ系で空間に形成された像を肉眼 で捉えることになるが，NMR では静磁場 $\left(H_{0}\right)$ 飞沶か れゼーマン分裂したエネルギー状態にある核スピン系 が，そのエネルギー差に対応したエネルギーのパルスラ ジオ波を吸収して励起状態となり，その後緩和する過程 を検出コイルによって位相検波し，フーリェ变換してス ペクトルを得る(1).さらに MRI は, NMR スペクトル を構成するパラメーターの空間的分布を画像化する(2). MRI では，集光にあたる作業においてコンピュータに よる演算がレンズの役割の一部として働いている。ここ
で MRI が高分解能 NMR 分光法と異なるのは後者が よくスプリットしたスペクトルを得よらとするのに対し て, 前者は磁場勾配を有効飞使用して位置に関する情報 を得ようとすることである。

たとえば，図１と図２に測定用に用いられるパルスシ

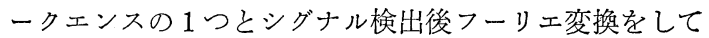
得られる画像シグナルを示す. $H_{0}$ に $X$ 軸の磁場勾配 $\left(G_{X}\right.$ : 図 $1 ， X$ 軸のシグナル検出時の磁場勾配) を与兄 ると核スピンの共鳴周波数は位置の違いによって,

$$
\begin{aligned}
& \nu_{1}=\gamma\left(H_{0}+X_{1} \times G_{\mathrm{X}}\right) / 2 \pi \\
& \nu_{2}=\gamma\left(H_{0}+X_{2} \times G_{\mathrm{X}}\right) / 2 \pi
\end{aligned}
$$

のように異なってくる.ここで拄は共鳴周波数， $X_{\imath}$ は $X$ 軸上の位置, $\gamma$ は磁気回転比である.これを $\nu_{0}=\gamma$ $H_{0} / 2 \pi$ の周波数で検波すると,

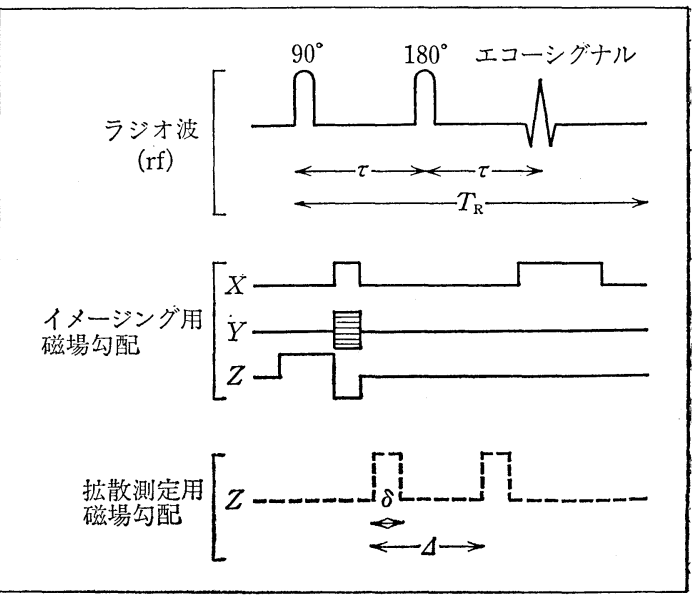

図 1"イメージ測定用のパルスシークエンス（2D-FT 法)

ラジオ波 $(\mathrm{rf})$ シークエンスの $2 \tau\left(T_{\mathrm{E}}\right)$ はエコー時間, $T_{\mathrm{R}}$ は ラジオ波の照射繰り返し時間. $X$ 軸の磁場勾配はシグナル取り 込々時飞位置情報を与兄る. $Y$ 軸は位相変調飞よって位置情報 を与克る， $Z$ 軸はスライシング用磁場勾配である。最下段の破 線の磁場勾配は拡散測定時にの文使用する。 $\delta$ はパルス磁場勾 配の幅で $\Delta$ は拡散時間. 
(a)

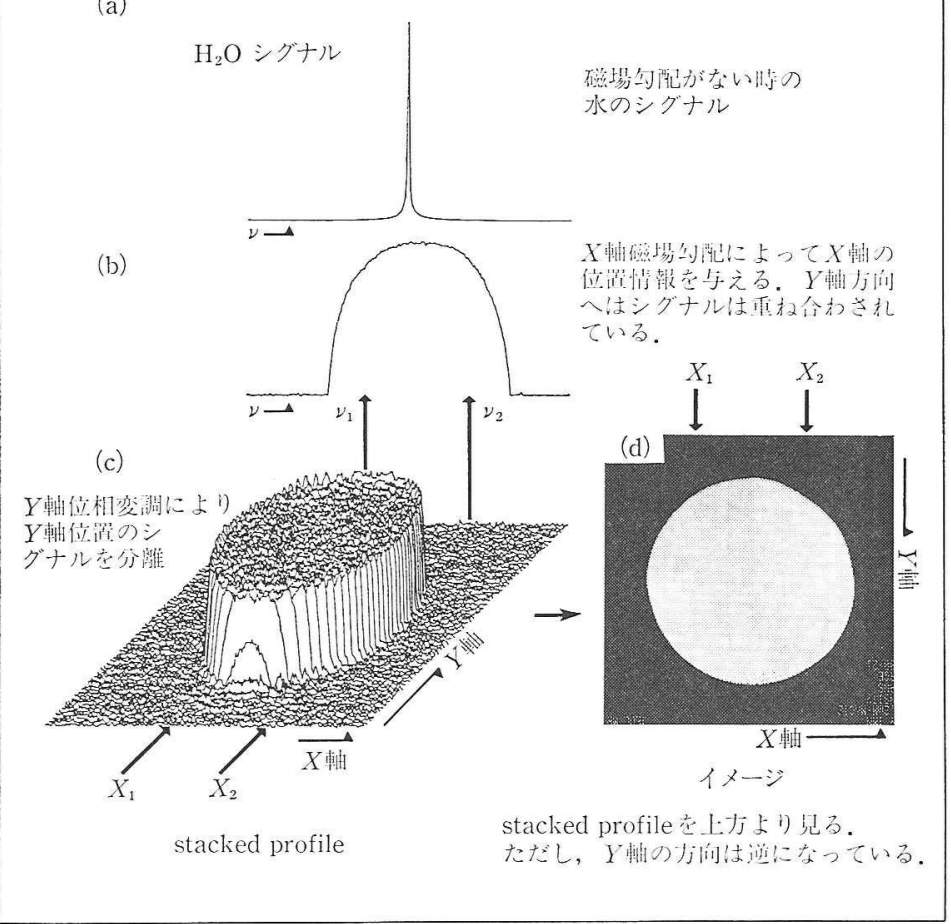

図 2 m $\boldsymbol{X}$ 軸および $\boldsymbol{Y}$ 軸磁場勾配による位置情報の決定

イメージ測定の厚みは $Z$ 軸スライシングによって決定される. 武料は水を入れた径 7 $\mathrm{mm}$ の試料管.

rf で磁化を反転して，て時間後に現 われるェコーシグナルを磁場勾配の 存在下で検出する. $180^{\circ}$ パルス rf (refocus パルス) を用いたエコーシ グナルは，場所による静磁場のミク 口な不均一性と磁場勾配の立ら上が りや切り下がりのために起こるシグ ナルのブロードニングを防ぐ目的で 使われるが，場合によっては FID (free induction decay; 自由誘導減

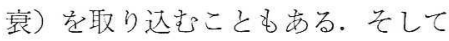
励起した磁化の緩和する時間 $\left(T_{\mathrm{R}}\right.$ : 繰り返(時間) 待って, $Y$ 軸方向に 与えた磁場勾配で沈められる位相の 変調（エンコード）に従って測定を 繰り返す。得られた $Y$ 軸エンコード 回数分繰り返し测定されたシグナル は, 二次元フーリエ変換された後イ メージプロセッサーに送られて画像 化される. $256 \times 256$ マトリックス で画像データを作製するために約 $0.5 \mathrm{M}$ バイト程度の大きなメモリ 一を必要とする. MRI ではパルス

$$
\begin{aligned}
& \nu_{1^{\prime}}=\gamma \times X_{1} \times G_{X} / 2 \pi \\
& \nu_{2^{\prime}}=\gamma \times X_{2} \times G_{X} / 2 \pi
\end{aligned}
$$

となって位置を示すシグナルは周波数軸上のシグナルと して検出することができる（図 2-b，ファントムの $X$ 軸).このようなシグナルを $Y$ 軸方向に短い段階的な磁 場勾配を与光（図 $1 ， Y$ 軸エンコード用磁場勾配）， $Y$ 軸 位置によってスピンの位相を变えて測定すると $Y$ 軸方向 の画像シグナルが分離して， $X$ 軸および $Y$ 軸に関してど の位置にどれだけのスピンが存在するかといらことがわ かる (図 2-c).

一万, 静磁場に磁場勾配を与えて拈いて（図 1，Z軸 の磁場勾配), 周波数の比較的均一な, または励起带域 幅の狭いラジオ波（rf）で励起（選択励起）すると, あ る空間に存在するスピンのみが共鳴する.このようにし て、イメージを測定するためのスライス面を形成する。

シグナルは図 1 のよらなスピンエコー二次元フーリェ 変換 $(2 \mathrm{D}-\mathrm{FT})$ 法で測定される場合が多い。まず, $90^{\circ}$ パルス rf で磁化を励起し， $\tau$ 時間待って，180只ルス $\mathrm{rf} の$ 発生タイミングのコントロール, 磁場勾配のコン トロール，位相検波，フーリエ変換，画像作製など，光 学顕岍鏡に和けるレンズに相当する部分はコンピュータ のかたまりであると考えてよい.

こらして得られた画像は,一見, 形態のイメージに見 えるが，実際には前に述べたよらに光学顕微鏡とは異な った意味をもつ画像である。多量に水を含む生体組織で は，一般的には水の量と運動性を反映したシグナル画像 となる(3).

MRI のバリエーションである NMR 顕微鏡の特徽 は，高い空間分解能を得るために強い安定した磁場勾配 を発生させる必要があることである。磁場勾配が強けれ ぼ強い活ど空間的な位置の変化に対して周波数の变化が 大きくなるが，一方に拉いては磁場勾配の立ち上がりや 切り下がりの際の磁場の乱妃でスペクトルの線幅が広が り，画像がわがむ原因となる。また，画像の空間分解能 を上げると，1画素 (voxel) に存在するスピンの量が少 なくなり，NMR として検出感度のよい核たと点ばプ 
ロトン $\left.{ }^{1} \mathrm{H}\right)$ は測定対象となりらるが，医学用または大 型 MRI で重要な生体情報を与える ${ }^{31} \mathrm{P}$ の検出など(4)は 不可能となる。

水の分布と運動性をもとに異なる性質の組織を識 別する

プロトンの其鴆周波数に rf を合わせ，検出コイルを 同調させれば，生体中に豊富に存在する水の分布を画像 化することができる、シグナル強度は水の量ばかりでな く，運動性を含んだ関数(ら),

$$
S=N_{\mathrm{H}} \times\left(1-2 \times e^{-T_{\mathrm{R}}-\left(T_{\mathrm{E}} / 2\right)}+e^{-T_{\mathrm{R}} / T_{1}}\right) \times e^{-T_{\mathrm{E}} / T_{2}}
$$

で表わされる，普通に画像を作製すれば，高い運動性を もつ水の分布を見ていることになる．したがらて，水の シグナルを通して組織内の黑なる器官の性質の違いを非 破壊的に観察することが可能で方る.

上式を見ると, シグナルの強度 $(S)$ はスピン数 $\left(N_{\mathrm{H}}\right)$ と $T_{1}$ (スピンー格子緩和時間), $T_{2}$ (スピンースピン緩和 時間) によって表わさ机るスピン系の軍動性に依存して いる，そこで， $T_{R}$ （図 1）を幾段階かに変光て測定する

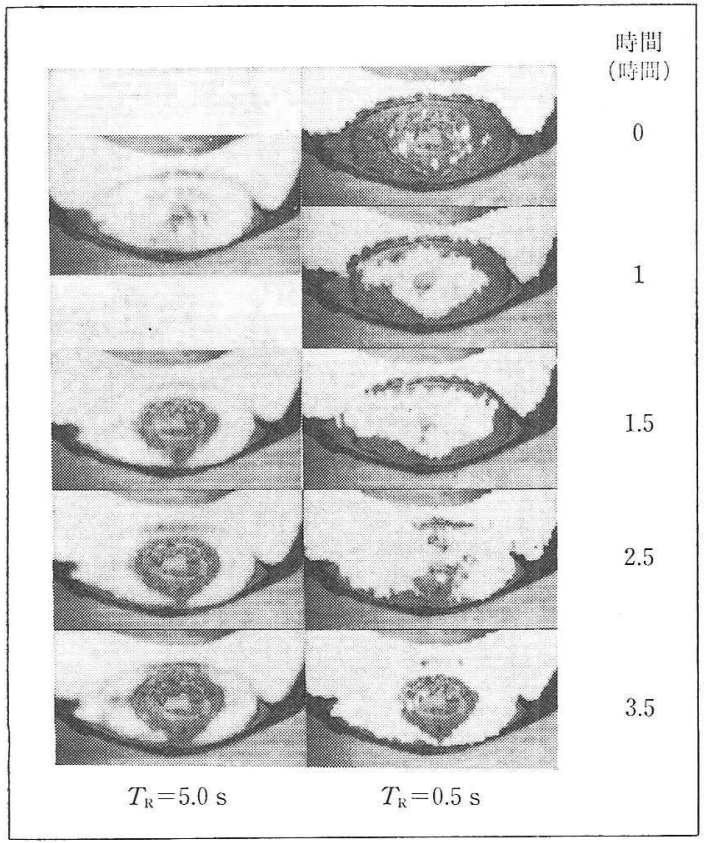

図 3 緩和試薬 $\left(\mathrm{Mn}^{2+}\right)$ を用いた水の移動の追跡（才 オムギ幼芽)

顕微鏡写真に NMR イメージを重放合わせてある（白いイメー ジが NMR イメージ)。

左: $\mathrm{Mn}^{2+}$ の取り込まれた部位のシグナルが弱くなる，右： $\mathrm{Mn}^{2+}$ が $0.2 \mathrm{mM}$ に達した部位のみ強調され，それより濃くても薄く てもシグナルは弱くなる。つまり組織による吸収速度の違いが わかる。
ことによって $T_{1}$ を，また $T_{\mathrm{E}}$ (図 1 ，エコー時間）を幾 段階かに変えて測定することによって $T_{2}$ を計算するこ とができる． $T_{1}$ または $T_{2}$ の值を画像化したものが緩和 時間イメージ（ $T_{1}$ または $T_{2}$ イメージ）であり，水の運 動性の部位による変動を示す．細胞中の代謝基質やイ才 ンの輸送, $\mathrm{O}_{2}$ や $\mathrm{CO}_{2}$ の交換扣よび代謝反応によって生 成された熱の排出には水相が関与しているので，代謝速 度は水の移動速度に依存して和り，したがって水の運動 性は代謝速度および器官を構成する細胞の活性を間接的 に表わしているものと考えられる(6).

組織，器官拉よび細胞間の性質の違いを検出するため にイメージングにおいてよく用いられるものに緩和試薬 がある、緩和試薬はスピンとの相互作用によってスピン 系の緩和を速くする効果をもつ、植物を対象として用い られるものに $\mathrm{Cu}^{2+}$ と $\mathrm{Mn}^{2+}$ がある。これらを吸収した 部位の水の緩和時間は短くなり，吸収した部位と吸収し なからた部位とを区別することができる。また， $T_{R}$ を 短く設定して測定することによって，吸収した部位を強 調して示すことも可能である。このように異なる性質の 部位を区別するための試薬をコントラスト試薬といらこ ともある。植物を刘象とした研究では， $\mathrm{Cu}^{2+} や \mathrm{Mn}^{2+}$ は水の移動のトレーサーとして用いられ, 一見, 均一 に見觉る細胞問で水の移動速度が異なることがわかる (図 3).

\section{選択励起一一局所スペクトルとケミカルシフトイ メージ}

前述のように, MRI 拈よび NMR 顕微鏡においては 磁場勾配を駆使することによって必要とする情報を得よ らとすることが特徵である．その手法の一つが磁場幻配 による空間的に限定したスピンの選択励起である。磁場 勾配 $\left(G_{\mathrm{Z}}\right)$ を与えた上で $\mathrm{rf}$ を照射すると， $Z$ 軸方向の 励起幅を $\Delta Z$ として

$$
\Delta Z=2 \pi \Delta \nu_{\mathrm{rf}} / \gamma G_{\mathrm{Z}}
$$

の空間のスピンだけが励起される(2,7).ここで， $\Delta \nu_{\mathrm{rf}}$ は キャリヤー周波数を中心とした励起帯域幅である. $\Delta \nu_{\mathrm{rf}}$ $\propto 1 / t_{\mathrm{W}}$ となり，パルス幅 $t_{\mathrm{W}}$ (時間) に逆比例するので, 長いパルス幅の rf と強い磁場勾配を使えば選択励起の 空間領域を狭くすることができる。この時フーリエ変換 後シグナル形状が矩形となるようにシンク（ $\operatorname{sinc）パル~}$ スが用いられる。普通，イメージングでは、この方法を 
イメージを構成するサンプルの厚みを決定するために使 用していて（図 1，Z軸磁場勾配），スライシングと呼ん でいるが，これをイメージ上のX軸の一部を選択的に励 起するために使用してみる.

パルスシークェンスを図 4 に示す. $X$ 軸の選択励起は $180^{\circ}$ refocus rf パルスと同時に磁場勾配を与えて行な い,シグナルを磁場勾配なしに取り込むと，イメージと 同一スライス面に括けるX軸上の限定された部位のスペ クトルを測定することができる.図5のように（a）に ${ }^{1} \mathrm{H}-\mathrm{NMR}$ イメージ（b）にそのイメージのX軸上の中 央（ $\alpha$ ) を選択的に励起した時のスペクトルをイメージ 化した画像を示すと，スペクトルのイメージ（b)は，X 軸はケミカルシフト，Y 軸は ${ }^{1} \mathrm{H}-\mathrm{NMR}$ イメージ（a） の $Y$ 軸位置と対応した部位のスペクトル強度を示してい て、1本1本のスペクトルを取り出すと（d）に示した ようなスペクトルとなる. スペクトル上で $4.8 \mathrm{ppm}$ 付 近のシグナルは水, $3.6 \mathrm{ppm}$ 付近のシグナルは糖である から，スペクトルイメージ (b) の 左のシグナルは水, 右は糖を示す. $X$ 軸の選択励起位直は rf の中心周 波数を変えることにより左右に変化 させられるので, ${ }^{1} \mathrm{H}-\mathrm{NMR}$ イメー ジ上の任意の局所に限定したスペク トルを容易に得ることができる（た だし，X軸の選択励起幅は $1 \mathrm{~mm}$ 程 度, 画像のスケールと比較された w).

このような方法で, たとえば,糖が 組織中のどの部位に存在しているか を知ることができるが，存在部位の 検出に関しては, さらに巧妙な手法 ケミカルシフトイメージング(8)が知 られている。長いパルス幅の rf 用いて最初にスピンを励起するとき にケミカルシフト上の糖の範囲のみ を励起すると，糖のシグナルによる 画像を得ることができる、しかし， 植物では糖の含量は低く, 組織に多 量に含まれる水とケミカルシフトが 近いため, 正確なケミカルシフトイ メージングが困難である場合が多
い. 局所スペクトルに戻ると, これらのスペクトルは本 来化合物の構造についてミクロな情報を含み化合物を同

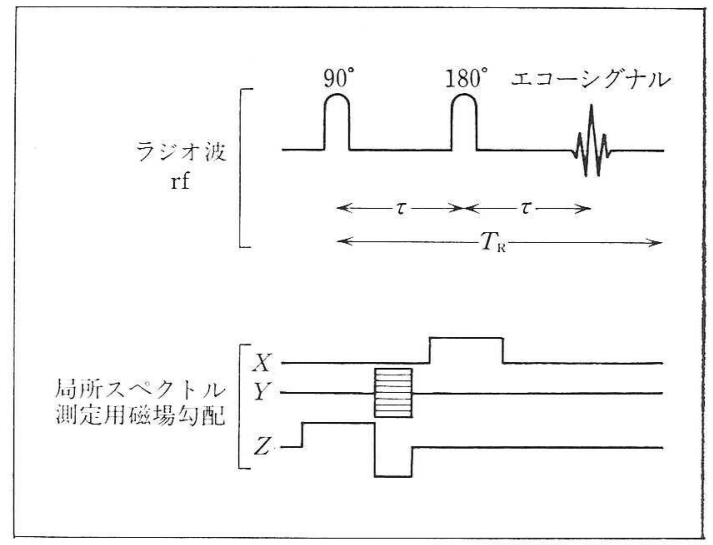

図 4四選択励起による局所スペクトル測定用のパルスシ ークエンス

$X$ 軸位置の選択は $180^{\circ}$ refocus rf 之同時に $X$ 軸磁場勾配を与 えて行ないシグナル取り込み時には磁場勾配を与えないＹ 軸执よびZ軸は 2D-FT 法（図 1) と同様である。

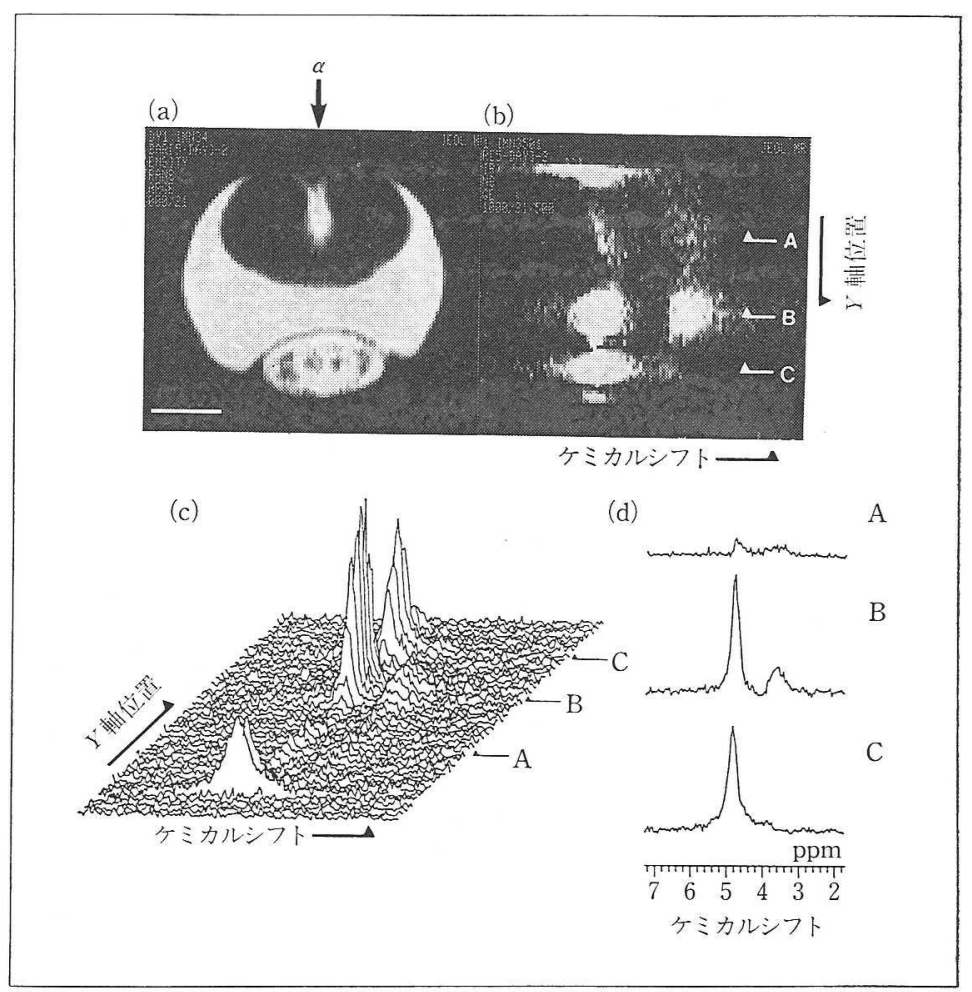

図 5 四オオムギ発芽種子の ${ }^{1} \mathbf{H}-\mathbf{N M R}$ イメージ (a), ${ }^{1} \mathbf{H}-\mathbf{N M R}$ 局所スペ

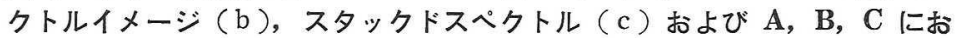
けるスペクトル (d)

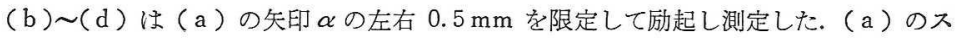
ケールは $1 \mathrm{~mm}$. 
定することが可能なはずであるが，植物組織のような空 気を多量に含み不均一な成分と構造から形成されている 試料では，静磁場が乱されてスペクトルがブロードニン グして糖の種類の同定が可能なほどのシグナルスプリッ トを得ることは難しい。また，分解能の良い ${ }^{13} \mathrm{C}-\mathrm{NMR}$ を用いるためには化合物の濃度が低すぎるようである。

さて，磁場勾配を用いた選択励起法の巧妙な例として センシティブポイント法(2)がある. $X, Y, Z$ 軸の 3 方向 に各々振動磁場勾配を与克, FID を取り込み積算して 時間平均し, 磁場勾配の中心位置のみからシグナルを得 る、シグナルを得ることのできる部位の大きさは磁場勾 配の振動周波数に比例し強度に逆比例する。ただし，測 定中にも磁場勾配を与党るためスペクトルのかなり強い ブロードニングは避けられない。

\section{さらに磁場勾配を活用する——拡散イメージング}

磁場勾配を用いてスピンの存在位置に依存した位相を 与え，位置の情報を得る方法は，スピンエコー $2 \mathrm{D}-\mathrm{FT}$ 法（図 1）に和ける $Y$ 軸位置を決定するために使用され ているが，この方法に一ひ称り加えて，組織内に拈ける 水またはイオンの移動を测定する。水の移動を测定する ためには，図 1 に示すパルスシークエンスの最下段のパ ル大磁場勾配 ( $Z$ 軸) を積極的に使用する. $90^{\circ}$ パルス rf でスピンを励起した後, 強い破線のパルス磁場勾配を
与えると, 磁場勾配に沿った位置によってスピンの角速 度が変わり，シグナルの位相が異なってくる。その後, $180^{\circ}$ refocus rf パルスを照射して $T_{2}$ 成分の位相の乱れ を元に戻す操作を行ならがここれだけではスピンの位相 が位置によって異なっているためにエコーを結ばない。 ここでもら一度, 前と同じ強さのパルス磁場勾配を与え ると, 位置の位相を位置に無関係な位相に戻しエコーを 結ばせることができるが，この時，前のパルス磁場勾配 を与えた時点に和ける位䈯から移動した分子のスピン は, 同じ強さの磁場を受けることができないので位相は 元に杘らなくなる、つまり，2つのパルス磁場勾配の間 ( $\Delta$ : 拡散時間) に空間的に磁場勾配と同じ方向に移動し た分子の分だけ弱いシグナルが得られることになる(1) (図 6-b).ここで使用されるパルス磁場勾配は分子の移 動速度が遅いほど強いパルス磁場勾配が必要であり，イ メージング用磁場勾配 ( 10 Gauss $/ \mathrm{cm})$ の数倍も強いも のを用いる場合がある. 一方, 生体中の自由水のように 移動の速いものでは 10〜 30 Gauss $/ \mathrm{cm}$ 程度でよく, 逆に イメージング用磁場勾配が桩散効果をもつ場合がある.

ここで紹介したパルス磁場勾配のスピンの位相に詨寸 る作用は, 最近, 急速な発展を遂げているタンパク質の 構造解析のための测定において, 多量に含まれる軽水の 大きなシグナルを水分子とタンパク質分子の移動速度の 差を利用して消去するために活用されている.
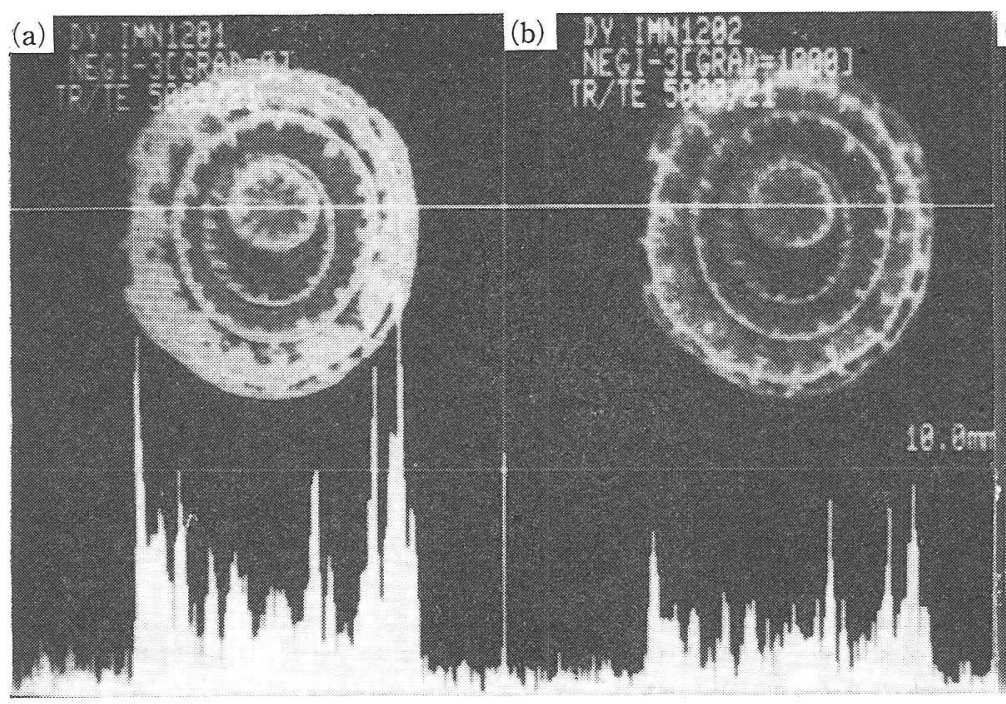

(c)

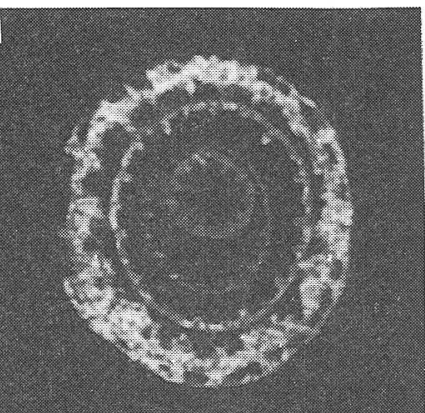

図 6 四ケギの ${ }^{1} \mathrm{H}-\mathrm{NMR}$ イメージ ( a ), 拡散イメージ (b) および計算により求めた拡散係数イメージ（c） 下のプロファイルは図中の横線に沿ったシグナル強度を示す。抎散測定用パルス磁場勾配の印加により（b）のシグナル強度は（a） に比べ低下している. 
以上のようにして測定したイメージは, 拡散を強調し たイメージまたは拡散効果を加えたイメージといらこと になるが, 実際の水の移動速度を表わす拡散係数は, 通 常の ${ }^{1} \mathrm{H}-\mathrm{NMR}$ イメージと拡散イメージ（図 6-a, b) を もとに計算しなければならない、拡散係数の計算は, 一 般には, イメージング用の画像処理装置がサポートし ていないので，他のコンピュータにデータを転送して Stejskal-Tanner の式(9)に従って計算して, 再びマトリ ックス上に画像データを作製することになる.この時, 計算結果の領域に合わせて, 画像データの階調を決定し て組み込むことが重要な作業である（図 6-c）.

MRI ではイメージ測定時に画像中の組織を区別して 識別するためのコントラストをつけるように, 種々の測 定用パルスシークエンスが工夫されているが, 複数の画 像データを用いた演算で得られる二次データを画像化す ることも非常に重要なことである。たとえば， $T_{1}$ およ び $T_{2}$ イメージもその例であるが，最近，Callaghan ら によって流れをもつ水のイメージ化の興味ある試み(10) が提出されている.これは組織の生理機能のイメージン グである. 演算結果のイメージングは, ${ }^{1} \mathrm{H}-\mathrm{NMR} ミ ク$ ロイメージング (顕微鏡) が形態観察の意味合いの強い 手法から組織の機能を表現することを明確に目的とした 手法に発達するための重要な過程であり, 強力なへルパ 一であると考えられる. そのためには，数十枚に及ぶ巨 大なイメージデータ用のメモリー と, 複雑な演算を可能とするための 高速コンピュータが不可欠である.

\section{高速コンピュータと MRI}

コンピュータの性能の向上を頼り に多次元フーリエ変換を行なえば, 選択励起法を用いなくても，比較的 容易に二次元空間に拈ける，または 平面画像上の任意の位置の局所スペ クトルを得ることができる， $Z$ 軸の 選択励起の後, $X$ 軸, $Y$ 軸におの拉 の $G_{\mathrm{X}}, G_{\mathrm{Y}}$ の磁場勾配を加えて位相 変調をして測定し, その後, 静磁場 の不均一性によって起こる位相のず れを補正するための $180^{\circ}$ refocus rf パルスを与える.そして磁場勾配な
しにェコーシグナルを測定する，位置情報は $X$ 軸, $Y$ 軸 ともに位相変調の形でシグナルにエンコードされる. 得 られたシグナルを三次元フーリエ変換すると, スペクト ロスコピックイメージングを行ならことができる．本方 法で測定したデータをもとにして，スペクトルデータよ り得られる化合物の平面分布か，またはイメージ上の任 意の限定した部位に持けるスペクトルを得ることが可能 である.この測定では, 後で必要とする情報を自由に取 り出すために充分な情報が蓄積される，ただ，磁場勾配 によるエンコードを $X$ 軸, および $Y$ 軸の両方に行ならた めに通常の $2 \mathrm{D}-\mathrm{FT}$ 法 (図 1) の $n$ (エンコード回数) 倍の時間がかかり，この時間の延長は生体試料を取り扱 らときには, シグナル積算を考慮するとかなりの負担と なる・

NMR 顕微鏡へのもら一つの期待は, 細胞の反応, ま たは水の移動などのリアルタイム計測である. そのため には 1 測定数十分以上かかっているイメージの測定時間 (これは水の完全緩和にかかる時間（5 秒ではまだ短い） とエンコード回数と積算回数によって決定される）を短 縮することである.イメージングに拉いて測定時間がか かるのは， $Y$ 軸方向の位置情報を得るために位相変調に 従って繰り返しシグナルを取り达むためである（図 1). 図 7 に示すよらに, $90^{\circ}$ パルス $\operatorname{rf}$ の後, $X$ 軸方向の位 置情報を得るための $X$ 軸の磁場勾配を与充ながら反転す

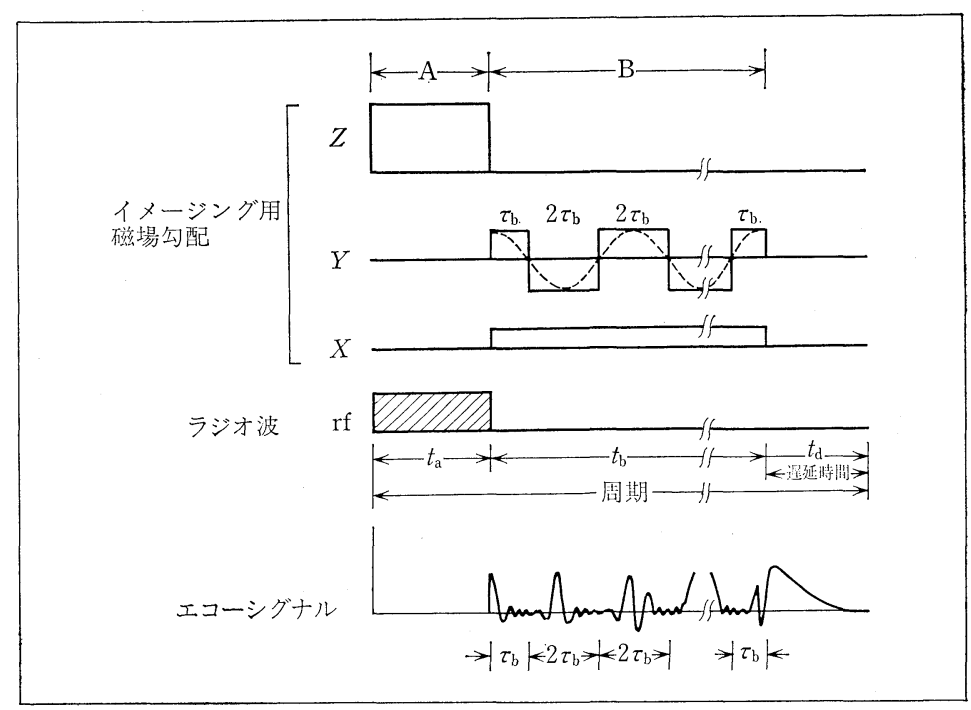

図 7 エコープラナー法のパルスシークエンス(7)

$Z$ 軸の磁場勾配はスライシソグ用， $Y$ 軸の磁場勾配はシグナルのエコートレーンを作 るため周期的に反転させて $Y$ 軸の位置情報を得る。 $X$ 軸の磁場勾配は $X$ 軸位置情報を 与える。 
るY軸磁場勾配によってェコートレ ーンを形成すると，ごく短い時間 (数十ミリ秒) で画像データを取り 込むことが可能である。このンーク エンスは Carr-Pursell の $T_{2}$ 測定 のスピンェコートレーンとよく似て おり，エコープラナー法と呼ばれ $z^{(7)}$.

この方法の变形でスペクトロスコ ピックイメージングを行ならことが できる(2)，2 D-FT 法のシークェン スに执いてェコーシグナル取り込み の時に短い間隔 $\left(\tau^{\prime}\right)$ で $X$ 軸方向の 磁場勾配を反転させるとェコートレ ーンを形成することができる。この エコートレーンはX軸方向の位置情 報と同時にスペクトル情報を含んで
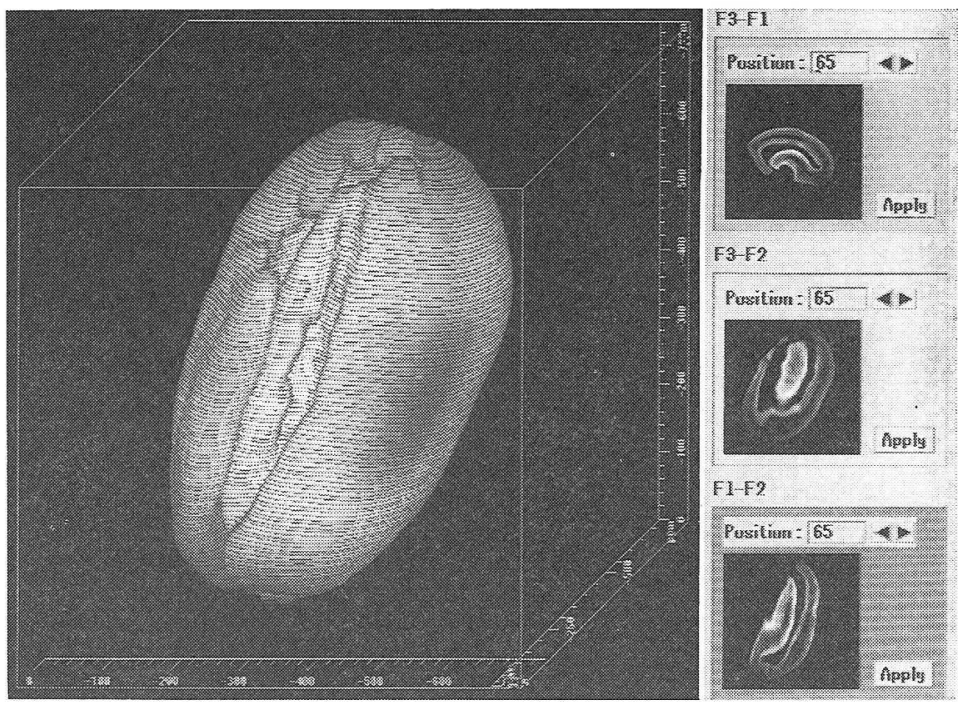

図 8四コーヒ一豆の三次元 ${ }^{1} \mathrm{H}-\mathrm{NMR}$ イメージ

F 3-F 1 は $X-Y$ 平面, F 3-F 2 は $X-Z$ 平面, $F$ 1-F 2 快 $Y-Z$ 平面の中央部の断面 のイメージ，測定は $Y, Z$ 軸位相変調による(この立体イメージは日本電子, 今成司 氏と津野久幸氏より提供を受けたものである).
いる. その後, エコーシグナルの方向を合わせるために， メモリー上で奇数番目と偶数番目のエコーを分けてフー リエ変換する。このようにして前出の三次元フーリェ变 換によるスペクトロスコピックイメージングにおけるX 軸位置に関する位相変調を除き，測定時間を短縮するこ とができる.スペクトルシグナルのサンプリング間隔は $4 \tau^{\prime}$ (エコー時間の 2 倍) であるが， $\tau^{\prime}$ の設定は磁場勾 配の立ち上がり時間との関係で決定されるのでむやみに 短くすることはできず，スペクトルの観測範囲(サンプ リング間隔に逆比例する）が狭くなることが問題であ る.アクティブシールド型の高性能な磁場勾配コイルが 必要な理由である。

$Z$ 軸方向のスライス面の位置は rf の周波数を変える ことにより変化させることができる。そこで, rf の周波 数を変えながらイメージングを行なえば，三次元立体イ メージデータが得られることになる。また 2 軸位相变調 による高度な方法をとると, 三次元フーリエ変換によっ て立体イメージを得ることができる（図 8). 再び, 高性 能コンピュータの助けを期待しなければならない。しか し，立体イメージングにおいて問題となるのは別の事柄 である・まず， ${ }^{1} \mathrm{H}-\mathrm{NMR}$ の感度は他の核に比べればよ いが，それでも生体では，かなりの水が束縛された状態 にあるために $10 \mathrm{~mm}$ 程度の試料を扱ら場合, $50 \mu \mathrm{m} \times$ $50 \mu \mathrm{m}$ の pixel で $250 \mu \mathrm{m}$ 程度の厚みを設定しないと,
画素 (voxel) 中のスピンの量が不足して機能的に意味の ある良好な画像を得ることが困難である。そこで, 実際 的な分解能は voxel が立方体であるとして $80 \mu \mathrm{m}$ 程度 となる.イメージング時に，一方向（植物では成長布 向）を大きめに設定してイメージ構成時に補完法によっ て分解能を向上させても，本質的には大きな䛊りを含ま ない試料もある。このよらな場合でも，実際には，最も 良い分解能の場合で, $50 \mu \mathrm{m} \times 50 \mu \mathrm{m} \times 50 \mu \mathrm{m}$ 程度の voxel となるのではないかと考光ている。 これは植物細

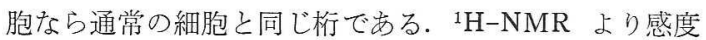
の劣る核種については, 顕微鏡レべルの情報を得ること は難しい。

次に, 画像データをどのように処理して, どのような パラメーターをどのよらな形で表示するかといら問題が ある、たとえば，三次元立体イメージデータから試料の 任意の位置に和ける任意の角度の画像を作製することが 可能であるが，それだけでなく，特定のパラメーターの 奥行きのある透視画像の作製など種々の表示方法の工夫 が必要である。これは画像またはスペクトルデータの測 定とは異なった問題とも考えられ，測定対象の性質をよ く知っている者とコンピュータグラフィックスのプログ ラム制作者との間の緊密な関係の上に成り立つ作業を必 要とするであろう. NMR はハードウエアそのものがコ ンピュータに強く侬存しているので, その進歩はコンピ 
ュータの性能の向上と一致している. 測定が三次元, 四 次元と進むに従って, メモリーの大容量化と計算速度の 高速化が必要となった.

NMR イメージングのコンピュータへの依存はそれだ けにはとどまらない.イメージデータの画像化と画像デ 一タ間の演算など画像処理装置が必要である。それも顕 微鏡というくらいであるから, データをある定まった方 針で解析して答えを得ればよいというのではなくて，測 定対象を様々なパラィーターで画像化して, その中から 生理的あるいは機能的に意味のある現象を見つけるため の観察の道具としなければならない. そのためには， 何枚ものイメージを並べて比較し, イメージ間の重䄈合 わせ, 演算, 疑似カラー表示, 輪郭強調, ノイズ消去, 階調変化, 場合によっては, 数十枚に及ぶ画像データを 用いて非線形最小 2 乗法によるパラメーター決定などを 必要とする場合がある. 現在は, これらの作業は, 1 枚 1 枚ポラロイド写真やビデオプリンターの画像として手 作業で比較したり, 画像データをパソコンまたはワーク ステーションに転送して, 適当な, もしくは自作のプロ グラムで処理している場合が多いが，これらの作業こそ 専用の高速コンピュータと幾台も並べられたモニター用 CRT を用いて行なわれるべきである. さらに，何枚も の画像データから計算で得られるパラメーターによって 作られた画像をグラフィックス化して, シミュレーショ ンを加えた方法で生理反応の解析ができると面白いと思 っている.

しかし, NMR 顕微鏡の現状は, 分解能の向上のため に立ち上がりの速いアクティブシールド型などの安定し た強い磁場勾配を発生させる装置や, 感度のよい検出コ イルの開発の過程にあるように見える. NMR 顕微鏡の 平面分解能は, スピン量の多い条件のよい試料に対し て $10 \mu \mathrm{m}$ 程度までは楽に達成できる. 最高の限界分解 能は $1 \mu \mathrm{m}$, 光学顕微鏡の限界と同程度が可能であると いわれているが, この領域になると, 生体では膜構造や 細胞の内容物と水の拡散の関係などが分解能を劣化させ る原因となるなど, 複雑な問題が出てくる.なお, 本稿 では触れなかったが, 最近, 開発されつつある固体イメ ージング(2)変興味ある注目すべき手法である.
像を提供する（内容的には異なる意味をもつ場合が多 い). そこで, 初歩的ニーザーである筆者らにとっては, 画像を作って眺めているだけでも親しみがわき, 飽きな いといら面をもっている. こんなところは光学顕微鏡と 似ているのではないかと思う。一方, 画像データの測定 法は複雑であり, 日毎に進歩し, スピンの rf と磁場勾 配に対する反応を巧妙に組み合わせて必要とするデータ を採取している、測定法のペーパーを囲んで「ああ，こ んなことをしているのか」と顔を見合わせて笑うことも しばしばである. あとは筆者らと同様, ただやみくもに 測定してみよらとする仲間が増えるのを待つばかりであ る. そらすれば, その後の画像処理, データ処理技術の 開発への安定した方針を見つけ出すことが可能となり， 光学顕微鏡では達成し難い非破壊的な機能イメージング ができるのではないかと考えている.

本稿の執筆に当たり, 機会を与えてくださった食総研の田中 芳一部長, NMR 顕微鏡に関して御教示いただいた JEOL デ 一タムの小川秀次郎氏, 日本電子の今成司氏と津野久幸氏, そ して協同研究者である小泉美香さんに感謝いたします。

\section{文献}

1) T.C. Farrar \& E.D. Becker : "Pulse and Fourier Transform NMR”, Academic Press, 1971 ; “パルスおよびフ 一リエ変換 NMR”, 赤坂一之, 井元敏明 訳, 吉岡書店, 1976.

2) 松井 茂: ‘NMR イメージング/スペクトロスコピー’, 現 代化学増刊 11 ; “高分解能 NMR”, 東京化学同人, 1987, p. 58.

3) N. Ishida \& H. Kano: Farming Japan, 28, 26 (1994).

4) K.H.Hausser \& H.K. Kalbitzer : "NMR in Medicine and Biology", Springer-Verlag, 1989, p. 173.

5) G. A. Johnson, J. Brown \& P. J. Kramer : Proc. Natl. Acad. Sci. USA, 84, 2752 (1987).

6) C.F.Hazlewood : "Cell-associated Water", ed. by W. Drost-Hansen and J.S.Clegg, Academic Press, 1979, p. 165.

7) P. G. Morris : “Nuclear Magnetic Resonance Imaging in Medicine and Biology”, Clarendon Press, 1986, p.77, p. 176.

8) L. M. Pope : “Magnetic Resonance Microscopy”, ed. by B. Blumich \& W. Kuhn, VCH Verlagsgesellschaft $\mathrm{mbH}$, 1992, p. 441.

9) E. O. Stejskal \& J. E. Tanner : J. Chem. Phys., 42, 268 (1965).

10) P.T. Callaghan: "Principles of Nuclear Magnetic Resonance Microscopy”, Clarendon Press, 1991, p. 420. 